\title{
7 The inadequacy of instrumentalist theories of procedural justice
}

\author{
Denise Meyerson
}

\subsection{Introduction ${ }^{1}$}

The requirements of procedural justice may vary depending on a range of matters. These include the nature and importance of the substantive interests at stake; whether the decision concerns the treatment of particular individuals or is a general policy decision affecting many people; whether decision-makers are required to decide by applying rules or standards which have been laid down in advance or free to decide as they think best in the exercise of their discretion; and whether decision-makers are private individuals or are exercising public power as governmental officials.

This chapter will be concerned exclusively with governmental decision-making that concerns the treatment of particular individuals, using 'government' in the broad sense in which it includes the judicial branch. By way of further narrowing the issues, it will focus on the procedures that should be used when decisions of this kind are made by applying pre-existing legal rules and standards, since, as DJ Galligan says, decision by the application of rules and standards is 'the characteristically legal mode' (1996, p. 24), involving, as it does, determining the content of the law, finding the facts, and applying the law to the facts. ${ }^{2}$ I will describe this activity as 'adjudicative', while noting that it is undertaken not only by judges, but also by administrative tribunals and administrative officials. ${ }^{3}$ This chapter asks how we should evaluate the justice of the procedures used for this task.

It is important to emphasise at the outset that when I talk about 'procedural justice', I am using the term 'justice' in a broad sense, rather than in the more traditional, narrow sense, according to which principles of justice are contrasted with consequentialist moral principles. Consequentialism holds that what makes an act right are its consequences, whereas principles of justice as traditionally conceived hold that individuals are entitled to be treated in certain ways even if the consequences are not overall beneficial. For instance, justice is frequently taken to require respect for rights as something to which individuals are morally entitled by virtue of their dignity and equality, even if this frustrates important social objectives. This is not necessarily to say that rights are absolute and should always prevail, no matter what the consequences, but rather to say that they enjoy great weight and cannot be straightforwardly balanced against consequentialist

DOI: $10.4324 / 9780429317248-11$ 
considerations. It follows that in the traditional sense of the word 'justice', a consequentialist theory using cost-benefit analysis as the basis for recommending particular procedural rules and practices will not count as a theory of procedural 'justice'. However, since I want to provide a sufficiently rich description of the theories on offer, I prefer not to exclude consequentialist theories by definition. Instead, I will follow Michael Bayles in describing as a theory of 'procedural justice' any theory that offers an account of the procedures that morality requires (1990, p. 9). Thus, when I talk about theories of procedural justice, I mean any normative theory directed towards justifying procedural requirements.

In particular, I count theories that evaluate procedures from the economic point of view as theories of procedural justice. As will be explained later, economic theories evaluate procedures by reference to the extent to which they allocate resources efficiently, which makes them consequentialist theories, rather than theories of justice in the narrow sense. Economic theories are nevertheless normative theories, since they maintain that it is morally desirable to design procedural rules so as to promote economic efficiency. ${ }^{4}$ Indeed, from their point of view, economic efficiency is synonymous with justice. Since it would impoverish the discussion to rule out economic theories on the ground that they are not strictly speaking theories of 'justice', and because it would be unfamiliar and inconvenient to describe economic theories as theories of 'procedural morality' (as opposed to theories of procedural justice), I have chosen to use the term 'theory of procedural justice' as shorthand for any theory that aims to specify which procedures are required by morality.

It is also important to emphasise that the procedures required by morality may diverge from the procedural requirements imposed by the law. This point may be obscured by the fact that the law helps itself to the language of morality when it describes the procedural obligations it imposes as requirements of 'natural justice', 'procedural fairness', and 'procedural due process'. Still, there is no guarantee that legal notions of what procedures are just, fair, and due will be morally sound. Since the law's understanding of procedural justice might not reflect a satisfactory understanding of the concept, the legal approach to these matters will not be dealt with here.

My main purpose in this chapter is to argue against the instrumentalist view that the only purpose of procedures in the adjudicative context is to lead to accurate outcomes. ${ }^{5}$ In Section 7.2, I explain that there are two kinds of instrumentalist account. What distinguishes them is their different attitude to conflicts between the achievement of accuracy and other social goals. The first account is willing to weigh the value of accuracy against its cost to society, while the second takes the view that accuracy-enhancing procedures are necessary to treat individuals fairly, even at some cost to society. Section 7.3 explores the difficulties with the first idea, and Sections 7.4 and 7.5 explore the difficulties with the second. The arguments made in these sections suggest that procedures must matter intrinsically as well as instrumentally. As to how we should understand the intrinsic value of procedures, Section 7.6 concludes with some brief remarks suggesting that procedural justice requires the use of procedures that promote 
relations of social equality between individuals and authority figures, especially governmental authorities.

\subsection{Instrumentalism introduced}

In the adjudicative context that is the subject of this chapter, there will frequently be a legally correct outcome to which the affected persons have a legal right (such as a right to social security benefits if they meet the relevant legal conditions or to acquittal if they are not guilty of a crime with which they have been charged). This makes procedures important because the procedures chosen to ascertain the facts and relate the law to the facts may be more or less suited to vindicate these substantive legal rights. To give an obvious example, judges are more likely to discover whether someone has committed a crime if they give defendants the opportunity to present evidence and arguments on their own behalf than if they toss a coin. In general, appropriate procedures can facilitate the discovery of relevant facts and make it easier to test the accuracy of factual and legal propositions (Bone 2017, p. 143). Since everyone will agree that giving effect to substantive legal rights has some moral value, it follows that the instrumental capacity of procedures to enforce the substantive law is one obvious way in which they can be judged for their justice.

But is contributing to the accuracy of legal outcomes the sole benefit to be derived from procedures, in which case it would follow that the value of procedures is entirely instrumental, being tied exclusively to the role they play in arriving at the right legal result? Empirical research into the psychology of procedural justice has shown that people do not see it this way. For instance, people value for its own sake the opportunity to present evidence and arguments on their own behalf, regarding this as fair in itself, and a requirement of justice, even when the correct outcome is obvious and there is no likelihood that the substantive rules will be incorrectly applied if they do not participate (Lind et al. 1983, p. 347; Tyler 1987, pp. 342-343; Tyler et al. 1985, pp. 79-80). In this chapter, I will give reasons for thinking that people's procedural justice judgements, as revealed by the empirical studies, are philosophically supportable: procedures matter for reasons other than the outcomes to which they lead. To this end, I will argue against two kinds of instrumentalist theory: economic theories and outcomebased theories. Both regard the avoidance of legal error as the only purpose of procedures. They differ, however, in their willingness to balance the benefits of accuracy-promoting procedures against their costs.

In order to understand this, it is necessary to note that procedures designed to avoid legal error are generally expensive. Economic theories take this into account by applying routine cost-benefit analysis, fixing on the optimal level of procedural accuracy by reference to considerations of cost-effectiveness. In Section 7.3, I criticise the economic approach. I argue that it fails to take our substantive legal entitlements seriously, since it makes no sense for the state to create legal rights with one hand but take them back with the other by allowing the procedures for enforcing these rights to be entirely dictated by economic considerations. If 
there are no principled limits on the extent to which procedural protections can be withheld in the public interest, it is difficult to see the point of recognising substantive rights in the first place.

Outcome-based theories agree with economic theories that the justice of procedures is solely a matter of the correctness of the outcomes to which they lead. However, they differ from economic theories in taking the view that '[i]t is a matter of injustice when judges make mistakes about legal rights' (Dworkin 1977, p. 130). Since they believe that adjudication engages issues of fairness to individuals, this leads outcome-based theorists to rule out routine trade-offs between the benefits of accuracy-promoting procedures and their costs. Unlike economic theories, outcome-based theories are therefore theories of procedural justice in the narrow sense of 'justice' explained in Section 7.1.

In Sections 7.4 and 7.5, I criticise outcome-based versions of instrumentalism. I begin by pointing out that there are practical limits on the instrumental value of procedures, since perfectly accurate procedures are unattainable and procedures that reduce error to the lowest possible level are too expensive. I argue that this fact creates a difficulty for outcome-based theories. Either they are forced to insist that procedural justice requires perfectly accurate procedures notwithstanding the fact that society cannot afford to provide them, or they are obliged to concede that procedural justice is compatible with substantively unjust (that is, legally incorrect) results. I argue that the first response implies, implausibly, that no real-world legal system can be procedurally just, and that the second response, although correct, pulls the rug out from under instrumentalism. In particular, once it is acknowledged that there is a disconnect between just procedures and just outcomes, it becomes difficult to see why providing concededly imperfect instrumental protection should exhaust the content of procedural justice. On the contrary, it is more plausible to infer that procedures must serve intrinsic values in addition to their capacity to enforce the substantive law. In light of this, I conclude by briefly considering the intrinsic values that procedures might serve.

\subsection{Economic theories of procedural justice}

Economic theories of procedural justice, as defended by theorists such as Richard Posner (1973, 2011) and Louis Kaplow (1994), analyse legal procedures from the perspective of the 'law and economics' school. Like utilitarianism, the law and economics approach takes the consequentialist view that legal rules should aim to maximise or produce the largest amount of the good (Weinrib 1980, p. 310). The economic approach differs from utilitarianism, however, in its view of what is good, being concerned to maximise wealth, not utility. ${ }^{6}$

In discussing the optimal design of procedural rules, Posner distinguishes between two types of costs: error costs and direct costs. Posner defines error costs as the economic costs caused when legal officials make erroneous determinations - for instance, when judges mistakenly impose legal liability or mistakenly fail to impose legal liability (1973, pp. 400-401). These errors are costly because they affect the extent to which people are deterred from violating the substantive 
law. For example, if people who have caused accidents are mistakenly found not to be negligent, then this will detrimentally affect the extent to which people will be deterred from engaging in negligent activities, and the cost of accidents to society will increase. Accuracy-promoting procedures (such as providing hearings and subsidising the cost of lawyers for defendants) help to minimise error costs and therefore promote compliance with the law, which is socially beneficial (Bone 2017 , p. 145; Kaplow 1994, p. 310).

Direct costs (or decision costs) are the costs associated with running a decisionmaking system - for instance, the time spent by legal officials and lawyers and the resources required to operate the system (Posner 1973, p. 400). Although procedural safeguards reduce error costs by producing information that increases the accuracy of the outcome, they are also expensive and therefore generate direct costs. Generally speaking, the more reliable a procedure is, in terms of the additional information it allows to be presented, the more it is likely to cost in time and money.

Posner argues that since the direct costs are just as real as the error costs, it would be irrational to provide procedural protections that reduce the error costs by 50 cents or even 99 cents but increase the direct costs by 1 dollar. In these kinds of cases, greater accuracy is, according to him, not worth the cost (Posner 1973, p. 401; see also Kaplow 1994, p. 308). Posner concludes that the objective of a procedural system is to minimise the total social costs (the sum of the error costs and the direct costs) $(2011$, p. 757). Or, as Kaplow puts the point, procedures should be 'efficient producers of information': the degree of accuracy they should afford is whatever degree is cost-effective (1994, p. 338, fn. 86). Since the only procedural entitlements recognised by the economic approach are to procedures that are economically efficient, it follows that we do not enjoy genuine procedural rights, viz. entitlements that should be respected even if this is not on balance beneficial for society.

The well-known United States case of Mathews $v$ Eldridge (424 US 319 (1976)) approaches procedural justice along these lines, as a matter of finding an optimal balance between the benefits of procedures and their costs, at any rate in the administrative law context. In justifying its finding that a procedure based on written submissions (as opposed to oral testimony) before terminating social security benefits provided sufficient due process, the United States Supreme Court stated:

identification of the specific dictates of due process generally requires consideration of three distinct factors: First, the private interest that will be affected by the official action; second, the risk of an erroneous deprivation of such interest through the procedures used, and the probable value, if any, of additional or substitute procedural safeguards; and finally, the Government's interest, including the function involved and the fiscal and administrative burdens that the additional or substitute procedural requirement would entail.

(pp. 334-335) 
The primary objection to the economic approach to procedural justice is that it is difficult to square with the fact that when society creates legal rights it undertakes to protect them, even if disregarding these rights would have better social and economic consequences. As Ronald Dworkin observes, 'someone is entitled to win a lawsuit if the law is on his side, even if the society overall loses thereby' (1985, p. 94). How can this entitlement be reconciled with the economic view that the only procedures that should be provided for the enforcement of substantive legal rights are those that are in the public interest? Although the decision to create a particular right may initially have been based on public interest considerations, the right thus created cannot be ignored just because it does not suit society to give effect to it. To quote Dworkin again, the 'boast' that society honours people's rights under the law even at the expense of the public interest is no more than an 'idle gesture' if the procedures necessary to enforce these rights can be denied 'for no better reason than that same public interest' (1985, p. 77). Along the same lines, Robert G Bone observes:

[t]he existence of substantive rights implies procedural rights. Because effective enforcement is critical to respecting a substantive right, limiting procedure for reasons of utility would be tantamount to limiting the substantive right on utilitarian grounds. Put differently, without the constraint of procedural rights, courts could undermine substantive rights in order to serve utilitarian goals by denying the costly procedures necessary for their enforcement.

(1999, pp. 993-994)

\subsection{Outcome-based theories of procedural justice}

Although both economic theories and outcome-based theories defend the instrumental view that the moral value of procedures depends solely on their ability to prevent legal error, there is a key difference between them. From the economic point of view, the value of accurate procedures lies in the contribution they make to maximising the good. By contrast, outcome-based theories are concerned with the just treatment of individuals. Outcome-based theories maintain that people suffer an injustice when they are deprived of their legal rights and they value accurate procedures for their ability to guard against this form of substantive injustice. Outcome-based theories are therefore fairness-based or rights-based theories, not consequentialist theories (Bone 2003, pp. 487-488, 495-496).

Outcome-based theorists make a distinction between two kinds of error costs: those that impose costs on society and those that impose costs on individuals. Posner is concerned only with the former-the social costs that arise when legal error prevents the purpose of the law from being achieved. For outcome-based theorists, by contrast, error can have a 'moral cost' as well as a social cost. This will be the case when individuals are mistakenly denied their substantive legal rights. Although legal errors do not always consist in a denial of legal rights, since some errors may be in the interest of individuals (e.g. the acquittal of someone 
who is guilty), outcome-based theorists maintain that when people are mistakenly denied their legal rights, this is unfair and a form of injustice (Bayles 1990, pp. 120-121).

Dworkin defends something like this view, ${ }^{7}$ arguing that we suffer a special kind of injury whenever our legal rights are not upheld. Using the example of a criminal trial, he says that someone who is mistakenly convicted and sent to prison does not experience only 'bare harm', such as the unpleasantness and frustration of being deprived of one's liberty (something that the guilty also suffer). In addition to this subjective form of harm, the innocent also suffer a further, objective injury, which consists simply in the fact that their punishment is unjust. Dworkin calls this kind of injury the 'injustice factor' in someone's punishment, or their 'moral harm', and says that it is a distinct kind of harm against which people should be specially protected. This requires procedures that make it possible for them to test their substantive rights (1985, pp. 80-81). Galligan makes the similar claim that "where the individual person is treated unfairly by being deprived of a right to which he is entitled, injustice results and the integrity of the process is called into question' (1996, p. 113). The injustice may be extreme, as in the case of wrongful convictions or 'miscarriages of justice' (Galligan 1996, p. 112), as we call them, but outcome-based theorists do not confine their claim to factually inaccurate determinations of guilt. In their view, any failure to uphold a legal right is the source of injustice. For instance, administrative decisions that deny benefits to individuals when they are entitled to them are unjust (Dworkin 1985, pp. 100-101; Galligan 1996, p. 112). ${ }^{8}$

In my view, outcome-based theories are correct to think that legal justice (upholding legal rights) is an aspect of substantive justice. Dworkin defends this position because he thinks that it is impossible to identify the law without recourse to moral reasoning. This means that there is, in his view, no clear distinction between legal rights and moral rights (1986, Chapter 7). It is not, however, necessary to endorse Dworkin's controversial view to understand why it is prima facie desirable to give effect to people's legal rights. As Galligan observes, legal standards give rise to normative expectations, including the expectation that one will be treated in accordance with the law. This expectation arises out of an implicit undertaking society gives to its members that their legal rights will be upheld. This does not mean that the commitment to treating people according to law can never be overridden-for instance, if a law is gravely unjust according to more fundamental standards of justice, this could be a reason to disregard it. It does, however, mean that treating people according to law is to treat them justly in one important sense of that term (Galligan 1996, pp. 58-62).

Since outcome-based theorists believe that the denial of legal rights is unfair and a form of injustice, and since avoiding injustice has some degree of priority over the public interest, it follows that outcome-based theorists reject the consequentialist idea that the benefits of accurate procedures should be routinely or straightforwardly balanced against their costs. They maintain, in other words, that procedures that increase the risk of mistakenly denying someone their legal rights cannot be justified by simply appealing to the benefits to society of saving 
money (Bone 1993, p. 598). A higher standard of justification must be met. Thus, in a discussion of the choice of criminal procedures, Dworkin expressly rejects a 'cost-efficient' approach, saying that questions of criminal procedure and evidence should not be decided 'entirely on the basis of cost-benefit calculations about the interests of society as a whole, balancing the interests of the accused against the interests of those who would gain from public savings' (1985, p. 73). According to Dworkin, the use of a utilitarian calculus for fixing criminal procedures denies the importance of moral harm (1985, p. 81), and implies that people accused of a crime are 'entitled to no particular level of accuracy at all' (p. 73).

It will be clear from the discussion so far that although outcome-based theorists emphasise the 'utility' of procedures in leading to accurate outcomes, they do not take a utilitarian approach to procedure, ${ }^{9}$ since they are not willing straightforwardly to balance the importance of achieving accurate outcomes against the cost of doing so. At first glance, then, it might seem that, unlike economic theories, outcome-based theories cannot be criticised for not taking our legal entitlements seriously. Matters are, however, more complex than this, as will shortly become apparent.

\subsection{Tolerating outcome error: Galligan, Dworkin, and Rawls}

If the purpose of procedures is to protect against the injustice that consists in denying legal rights, how robust must the protection be, according to outcomebased theorists? Any answer to this question must begin by acknowledging that procedural perfection is unattainable. There are no procedures available to us that are guaranteed to produce correct results (Solum 2004, p. 185). All procedures in the adjudicative context are attended by some risk of error, given what Bone describes as 'the cognitive and other natural human constraints on accurate decision-making' (2003, p. 514). It is not even feasible for the state to provide maximally accurate procedures, i.e. procedures that reduce unjust mistakes to the lowest possible level, since this would be so expensive as to severely limit the state's ability to provide for other important needs. In a context of limited resources, no one would prioritise accuracy over all other competing interests (Dworkin 1985, p. 84).

Since inaccurate procedures and the substantive injustice to which they lead are inevitable, whether because of human fallibility or limited resources, this leaves outcome-based theorists with two possibilities. They can insist that procedural justice requires perfectly accurate procedures, which carries the implication that procedural justice is unobtainable in the real world. Alternatively, they can narrow the concept of procedural justice, so as to adjust its demands to the constraints imposed by the real world.

Galligan takes the first approach. He argues that substantive rights justify a claim to whatever procedures are necessary to protect and uphold these rights (1996, p. 102). He writes: 
[o]nce it is recognized that to have a right is to have an undertaking from the community that a certain interest will be protected in a certain way, it is a short step to the conclusion that the undertaking ought to include the procedures and institutions necessary for the purpose. Procedures are part of what is necessary to take rights seriously and so to prevent unfair treatment.

(1996, p. 101)

Galligan concedes that society cannot afford to provide fully adequate procedures, and he also believes that if a society does its best to provide adequate procedures within the resources available, any inadequacy in the procedures provided is excusable. He insists, however, that to excuse is not to justify. In his view, there is no denying the fact that some of the resulting legal mistakes will violate rights and that these individuals will have been treated unjustly (1996, p. 116).

Dworkin takes the second approach. Although, as noted above, he appears to defend an outcome-based approach, he narrows the notion of procedural justice by reference to what is affordable, arguing that identifying procedural justice with maximum accuracy is too 'severe' a requirement $(1985$, p. 82), and that it is not unjust to provide less than maximally accurate procedures with a view to spending money on other worthwhile social programmes (1985, p. 72). It is not, however, clear that Dworkin's position is stable. How can one recognise the 'injustice factor' in certain kinds of mistaken decisions while simultaneously affirming that it is not unjust to tailor procedural protections to what is affordable? If certain kinds of mistaken decisions are unjust, it would seem to follow that people are entitled to robust procedures that protect their underlying legal entitlements, even if the expense involved cannot be justified from the economic perspective. On the other hand, if providing less than maximally accurate procedures in order to save money is not unjust, this would seem to be the equivalent of the costefficient approach defended by Posner. ${ }^{10}$

In an attempt to explain why affordability considerations can legitimately be taken into account within a rights-based framework, Dworkin argues that 'we do not lead our lives to achieve the minimum of moral harm at any cost' (1985, p. 86). Instead, we accept substantial risks of suffering injustice in order to achieve 'even quite marginal gains in the general course of our lives' (1985, p. 86). This shows, according to Dworkin, that we reject a 'grand right to supreme accuracy' (1985, p. 90). Does this mean that the economic approach is correct and that we have no procedural rights at all? Dworkin thinks not. He argues that it is possible to carve out a middle ground between the idea that we have a right to maximally accurate procedures and the idea that the choice of procedures should depend entirely on what is economically efficient (1985, pp. 72-73). This supposed via media can be found in procedural rules that are appropriately sensitive to the fact that denying people their legal rights is a form of injustice, while not regarding this kind of injustice as something to be avoided at any cost. Dworkin argues, in particular, for two procedural rights that are weaker than the grand right to supreme accuracy, but still genuine rights, according to Dworkin, because they trump ordinary utilitarian calculations (1985, p. 89). 
Dworkin derives these two procedural rights from the principle that political decisions must treat everyone with equal concern and respect. He argues, first, that when the legislature enacts procedural rules, it must show concern for moral harm by making an assessment of the magnitude of the moral harm caused when people are unjustly convicted or otherwise denied their legal rights. Thus a legislature would violate the first procedural right if, for instance, it refused to enact a procedural rule which would increase the accuracy of a trial at no additional cost to society, since that would indicate no concern at all with the risk of moral harm $(1985$, p. 89). At the same time, Dworkin rejects the idea that there is what Bone calls a 'normatively acceptable level of error risk' (2010, p. 1016). Provided that the legislature has attached importance to the risk of moral harm, it is free to decide how much to spend on procedures to guard against the risk, taking into account policy considerations and other competing social goals. This is because the first procedural right is

the right that a particular importance be attached to the risk of moral harm, not a right to a particular, independently describable, overall level of accuracy in adjudication ... [I]f a rule would improve accuracy by a great deal but cost the community heavily, then a failure to adopt the rule would be consistent with valuing the risk of injustice very high indeed.

(Dworkin 1985, pp. 95-96)

Dworkin thinks that it is fair to leave the decision as to how important moral harm is to the legislature because this is a moral issue about which people reasonably disagree. Furthermore, provided a legislative decision to sacrifice accuracy subjects everyone to the same risk, it will be fair to everyone $(1985$, p. 87$)$. The procedural rules chosen by different legislatures may therefore justifiably differ in the degree of protection they afford, since there is no one set of rules of evidence and procedure which is uniquely permissible when a legislature considers whether the social gains achieved by choosing less expensive and therefore less accurate procedures outweigh the moral harm that these procedures risk (Plaxton 2008, p. 364). This approach should not, however, be confused with a cost-benefit approach, according to Dworkin, because the decision is not a 'pure' matter of policy. On the approach prescribed by Dworkin, a legislature would not balance the 'bare' harm caused by mistaken decisions against the savings made by providing reduced procedural protections. It would weigh the interests of those who stand to be deprived of their legal rights much higher than that, because it would see them as interests in avoiding moral harm. A legislature following this approach could therefore not be accused of utilitarianism, according to Dworkin, even though it might ultimately take the view that scarce resources should be spent on social goals other than accuracy (Dworkin 1985, pp. 77, 94, 97-98).

The second procedural right for which Dworkin argues is the right to consistency in procedure. He maintains that once procedures have been established, they should be consistently applied (1985, pp. 89-90). If, for example, the number of jurors in a criminal case has historically been fixed at 12 , it would be a 
violation of the rights of accused persons if this number were to be substantially decreased. Even though there is no reason why a different number should not have been chosen initially, substantially winding back the protection would be unjustifiable, because it would diminish 'the level of safety provided at the center of the criminal process for so long' (1985, p. 91).

Dworkin (2002) expands on this idea in a more recent article considering United States anti-terrorism measures that dilute the rights of those accused of serious crimes. Dworkin concedes that the traditional rights of accused persons have evolved over time, that their details can be explained only historically, and that some of the procedural rights taken to be indispensable in the United States are not necessary features of all fair criminal justice systems. He maintains, however, that fairness requires, as a matter of equal concern for anyone who might be innocent, that the rights that have evolved historically are owed to anyone who is now accused of a serious crime and tried within the United States criminal justice system. It follows that it is unfair to persons suspected of terrorism to try them under special conditions that run an increased risk of convicting the innocent - for instance, before special military tribunals in which they have fewer rights than in ordinary criminal courts. Dworkin adds that if we believe that the danger from terrorism is so serious that we are justified in denying persons suspected of terrorism the traditional rights extended to other accused persons, then at least we should have 'the candor to admit that what we do to them is unjust' (Dworkin 2002).

In effect, Dworkin turns his back on the idea of outcome accuracy. Since his two procedural rights are not rights to the enforcement of one's substantive legal entitlements, but rather rights that guarantee that the risk of injustice created by inadequate procedures is fairly distributed across individuals, he turns procedural justice into a form of distributive justice (Bone 2010, pp. 1018, 1020; Galligan 1996, p. 119). This means that Dworkin does not carve out the desired via media between the purist view that we have a right to maximally accurate procedures and the economic view that we are entitled to no particular level of accuracy at all. Instead, he gives us an account of how to distribute scarce process resources fairly. As Bone observes, Dworkin tries to deal with the problem of limited resources by conceiving of procedural rights

as rights to fair treatment, not to accurate outcomes ... [E]rror does not violate procedural rights so long as the error is not due to skimpy procedures justified on utilitarian grounds and so long as the procedural system as a whole treats litigants fairly.

(Bone 1999, p. 934, emphasis in original)

However, even procedures that carry a very high risk of injustice may distribute the risk fairly. It therefore seems that we can ask the same question of Dworkin as he asks of the economic approach. It is central to Dworkin's rights-based theory of adjudication that society should honour people's substantive rights under the law even if this comes at a social cost. How is this to be reconciled with the idea 
that the only procedural rights we have are to a just distribution of the risk of error? Does the resulting mismatch between procedure and substance not entail that people's rights under the law are not rights in the strict sense, contrary to everything else Dworkin tells us about legal rights?

Galligan's approach is more coherent than Dworkin's. Dworkin attempts to have it both ways: insisting that society should honour people's legal rights while also maintaining that there is no specific or pre-defined level of accuracy which the procedures for enforcing these rights need to meet. Galligan, by contrast, connects substance and procedure as tightly as possible, since he holds that substantive rights justify a claim to whatever procedures are necessary to protect and uphold these rights. Procedural rights are therefore rights to procedures that always produce the right results (1996, pp. 113-114). In theory, this is an attractive position, because the idea that we are entitled to procedures that guarantee correct outcomes takes our legal rights with utmost seriousness. However, as previously noted, Galligan is forced to concede that inadequate procedures are unavoidable for practical reasons, such as resource limitations, which turns his conception of procedural justice into a utopian ideal. Galligan's purist approach implies that no procedural system in the real world can be just and that all legal systems violate people's procedural rights on a daily basis - a conclusion that is counter-intuitive. ${ }^{11}$

If Dworkin's procedural rights do not deliver on the promise of the outcomebased approach - that the purpose of procedures is to protect against the injustice that consists in the deprivation of substantive legal rights - and if Galligan's approach puts procedural justice out of reach, is there any other way of retaining the idea that people are entitled to procedures that are designed to vindicate their legal rights, while simultaneously narrowing the scope of procedural justice in response to considerations of affordability and efficiency?

The remaining possibility is that procedural justice requires giving substantial, although not absolute, priority to the value of accuracy over the public interest. If accuracy were to be prioritised in this way, procedures would be chosen that generate the right conclusion in the majority of cases, even if the expense could not be justified on utilitarian grounds. The risk of erroneous decisions would then be low, even if efficiency would justify running a higher risk. Moral harm would be avoided to a significant extent, and trade-offs between accuracy and cost would be permissible only once a morally acceptable threshold level of accuracy has been guaranteed. An approach of this kind would occupy a true mid-way position between the purist view and the economic view, since it would fix a morally acceptable level of risk of moral harm and identify just procedures with procedures that do not impose more than that level of risk.

Arguably, this is what Rawls had in mind when he said that the pursuit of correct outcomes in criminal trials competes with 'other ends of the law' (i.e. considerations of cost), and that 'imperfect' procedural justice is therefore the most the legal system can offer us. Rawls wrote:

[t]he desired outcome is that the defendant should be declared guilty if and only if he has committed the offense with which he is charged. The trial 
procedure is framed to search for and to establish the truth in this regard. But it seems impossible to design the legal rules so that they always lead to the correct result. The theory of trials examines which procedures and rules of evidence, and the like, are best calculated to achieve this purpose consistent with other ends of the law. Different arrangements for hearing cases may reasonably be expected in different circumstances to yield the right results, not always but at least most of the time.

(1971, pp. 85-86)

Along similar lines, Rawls describes due process as 'a process reasonably designed to ascertain the truth, in ways consistent with the other ends of the legal system' (1971, p. 239). This version of an outcome-based approach is superior to both Galligan's and Dworkin's approaches. It does not turn procedural justice into an unattainable ideal, à la Galligan. On the other hand, it takes the underlying substantive rights more seriously than Dworkin's approach, which rejects the idea of even a qualified right to accuracy and replaces it with a different kind of right altogether-one to the fair distribution of the risk of error. Yet imperfect procedural justice can still lead to substantive injustice, since procedures that satisfy Rawls's test (of yielding the right results most of the time) can lead to unjust results some of the time.

\subsection{Rejecting instrumentalism}

My discussion has shown that the relationship between procedures and legally correct outcomes in the real world is imperfect. Infallible decision procedures do not exist and maximally accurate procedures are too costly. If an outcomebased theorist responds by saying that people nevertheless have a right to perfectly accurate procedures, albeit one that cannot be met in practice, this means that procedural justice is not an ideal for the real world. On the other hand, if an outcome-based theorist concedes that considerations of cost reduce the scope of our procedural entitlements, and that procedures that are likely but not guaranteed to produce substantively just outcomes are sufficient to satisfy the demands of procedural justice (Rawls's view), this implies that procedural justice is compatible with substantive injustice. The risk of injustice is even greater on Dworkin's even weaker view that procedural justice merely requires a fair distribution of the risk of error. Dworkin's view approaches very close to economic theories of procedures.

Furthermore, once it is conceded that procedural justice is compatible with the violation of people's substantive legal rights, it becomes difficult to sustain the instrumentalist view that the only way to evaluate the justice of procedures is by evaluating the accuracy of the results to which they lead. Instrumentalism is at home within the economic framework of a cost-benefit approach to procedures, since a cost-benefit approach is, by definition, concerned only with the consequences of following different procedural rules. However, if one sees procedural justice as a matter of entitlements based in fairness to procedures that protect our 
substantive rights, and if one also concedes that the ability of just procedures to play this role is limited, the insistence that the only point of just procedures is to avoid violations of substantive rights becomes puzzling. Outcome-based theorists have not grappled with this question. Instead, they seem to regard the truth of instrumentalism as obvious.

Dworkin, for instance, quickly dismisses the view that there are 'process values', or that process can matter apart from outcomes. According to the process values view, certain procedures can be morally required even if they are not necessary to reach accurate outcomes (Summers 1974). For instance, participation in legal decision-making processes is thought by some theorists to be valuable independently of its instrumental value. Thus, it is argued that it is intrinsically unjust not to allow affected parties to participate by telling their side of the story, even if their participation will have no effect on the outcome, the case being cut and dried and the outcome obvious (Mashaw 1981, pp. 902-903). ${ }^{12}$ Dworkin responds to this claim by saying that he finds it difficult to understand how there could be any moral harm other than the harm of a mistaken decision and therefore how there could be any basis for finding procedures unjust other than the fact that they create a risk of substantive injustice (1985, pp. 102-103). Bone also gives the process values view short shrift. He says that the reason why we have an adjudication system is to produce quality outcomes, and defenders of the process values view therefore need to explain why people should be given participation rights without regard to whether this is needed to ensure outcome quality (2008, pp. 338-339).

The problem lies, however, in attempting to combine the claim that procedural justice is exclusively a matter of procedures that avoid injustice to individuals with the concession that just procedures are compatible with a substantial risk of outcome error. The effect is to turn procedural justice into an implausibly anaemic ideal—one that implies that there is very little that people are entitled to expect as a matter of fairness from the processes officials use to determine their legal situation. Procedures merely need to have some capacity to protect substantive rights or should distribute the risk of error fairly.

In my view, the solution is to reject instrumentalism. I agree with the outcome-based claim that procedural justice involves treating individuals fairly, not maximising benefits for society, and I also think that theorists like Dworkin and Rawls are correct to concede that even just procedures will not always be capable of protecting people's substantive legal rights. However, I draw the conclusion that there must therefore be more to procedural justice than being the servant of substantive justice. In particular, procedures should be assessed not only for their capacity to reduce legal error, but also for their intrinsic justice. Following intrinsically just procedures could then assist in offsetting the substantive injustice of the mistaken decisions whose possibility has to be accommodated within any real-world conception of procedural justice.

This raises the question as to what might make procedures intrinsically just. I will end by briefly explaining what kind of account I would offer in answer to this question. Some defenders of the process values view appeal to the value of 
dignity, understood as the capacity for rational agency. Thus, Jeremy Waldron argues that procedures should respect human dignity by treating people as active subjects, not passive objects - as people who can reason and explain themselves before decisions are made affecting them (2011, p. 19). Similarly, Laurence Tribe argues that it is unjust to deny persons the 'right to be heard from' and 'the right to be told why', because 'to be a person, rather than a thing, is at least to be consulted about what is done with one' (1988, p. 666, emphasis in original). For Tribe and Waldron, decision-makers are under an obligation to treat people in a way that respects them as rational agents, even if this is not necessary to achieve accurate results. ${ }^{13}$

Dignitarianism is not, however, the only way to understand the intrinsic value of procedures. The understanding of procedural justice in the empirical literature alerts us to another possibility-one that is not focussed on respect for rational agency. I mentioned in Section 7.2 that empirical research in psychology shows that people's understanding of procedural justice is not entirely instrumental or outcome-based. I did not, however, explain the non-instrumental concerns that dominate people's procedural justice judgements. The empirical studies show that these concerns are primarily focussed on the nature of people's social relationships with authorities - whether authorities are trying to be fair towards them, are treating them even-handedly and with respect, and are considering their views properly (Tyler \& Lind 2001, pp. 75-77). According to Tom Tyler and Allan Lind, it is 'striking how much issues concerning relationships to authority color the perception of [procedural] justice. Relational concerns seem to overwhelm concerns about the specific problem or dispute involved' (1992, p. 160). It seems that the reason why interpersonally satisfying interactions with group authorities are such a powerful influence on people's perceptions of fair treatment is because positive interactions send the symbolic message that one has equal status in one's group, which in turn promotes feelings of self-worth and self-respect (Tyler \& Blader 2000, pp. 90-92).

In my view, there are sound normative arguments supporting this alternative understanding of procedural justice, with relational theory in ethics providing the requisite normative underpinnings. Very briefly, relational theory emphasises the role of egalitarian social relations in an equal society. It defends the attractive idea that equality is an ideal that consists in people relating to each other as equals and enjoying equal standing (Anderson 2010; Scheffler 2003). As Catriona Mackenzie emphasises in her contribution to this volume, relations of equality are particularly susceptible to being undermined by attitudes of expressive disrespect on the part of state institutions and state officials. ${ }^{14}$ Relational theory therefore implies that officials are under a moral duty to interact with citizens in ways that communicate a message of equal status. As to what this might involve, the psychology research shows that it requires officials to treat people with respect, listen attentively, behave impartially, and demonstrate goodwill. In this way we arrive at a satisfying account of procedural justice that both dovetails with and justifies people's expectations about how officials should treat them. 


\subsection{Conclusion}

Although the value of accurate procedures must form part of any adequate conception of procedural justice, I have argued that instrumentalist theories of procedural justice are unsatisfactory. Economic theories do not take people's legal rights seriously, since the procedures they provide for the enforcement of these rights are fixed by reference to a cost-benefit calculation, which could lead to large-scale under-enforcement of the rights. It makes no sense to grant legal entitlements without recognising procedural rights that are to some extent insensitive to considerations of cost or social welfare more generally.

At the other end of the spectrum from economic theories, Galligan takes legal rights as seriously as it is possible to take them, since he insists that right-holders have a right to the perfectly accurate procedures needed to uphold their rights. I have argued, however, that his conception of procedural justice is unachievable, and that attempting even to approximate it would make it impossible to satisfy other important social needs.

Dworkin and Rawls recognise that maximal accuracy is too demanding a conception of procedural justice in a world of limited resources. This leads them to regard procedures as unjust only when the risk of error is not distributed fairly (Dworkin) or when the risk is too high (Rawls). Although I agree with them that just procedures are not capable of fully protecting legal rights, and that procedural justice is compatible with some degree of substantive injustice, I have argued that the difficulty is in combining this relatively insipid form of protection for legal rights with the instrumental view that procedural justice is nothing more than the servant of substantive justice. How can protecting substantive legal entitlements be the only purpose of procedure if it is such a flawed means to this end? I have claimed that it is more plausible to infer that there must be more to procedural justice than 'a process reasonably designed to ascertain the truth', to use Rawls's phrase. Procedures serve values other than reducing error and the moral assessment of legal procedures should not be limited to the outcomes they generate. Finally, I have suggested that relational theory in ethics enables us to grasp the aspects of procedural justice overlooked by instrumental accounts.

\section{Notes}

1 I would like to thank Catriona Mackenzie and Therese MacDermott for their very helpful comments. I am also grateful to participants who commented on aspects of this chapter when earlier versions were presented at the Law and Society Association Meeting held in Toronto in 2018, a workshop on procedural justice held at Macquarie University in 2018, and a seminar in the Philosophy Department at the University of the Witwatersrand in 2019. Wendy Carlton provided excellent editorial and research assistance. Some of the discussion in this chapter draws on material in Meyerson and Mackenzie (2018). Research for this chapter was funded by the Australian Government through the Australian Research Council's Discovery Project funding scheme (DP1701009600: ‘A Relational Theory of Procedural Justice'). 
2 For a discussion of procedural justice in the context of discretionary decisions, see Kristen Rundle's contribution to this volume (Chapter 11).

3 Compare Galligan (1996, p. 241): '[i]n a broad sense, all standard-application decisions are adjudicative, in that they require judgment in applying standards to facts'.

4 In Posner's view, 'morality is derived from the economic principle itself' (1979, p. 139).

5 In her contribution to this volume, Emanuela Ceva also provides reasons to reject what she calls the 'epistemic interpretation of the value of due process' (Chapter 8).

6 Posner defines wealth as 'the value in dollars or dollar equivalents ... of everything in society. It is measured by what people are willing to pay for something, or, if they already own it, what they demand in money to give it up' $(1979$, p.119).

7 Bone describes Dworkin's view as 'an outcome-oriented theory based on a right to treatment as an equal' $(2003$, p. 489 , fn. 10$)$.

8 Mistaken decisions in civil trials likewise cause injustice. For discussion, see Dworkin (1985, pp. 92-98).

9 Contra James Edelman, who maintains that tying the justice of procedures to their 'utility' in promoting accurate outcomes is equivalent to providing a 'utilitarian rationale for procedural fairness' (2016, p. 148).

10 See also Bone's observation that procedural rights present a puzzle in that '[b]ecause they are rights, they must resist arguments for limiting procedure based on the high social costs of litigation, but to fit prevailing intuitions of procedural fairness, they must also yield to social cost arguments at least to some significant degree' (2010, p. 1013).

11 Compare Bone (2010, p. 1016): if people have a right to perfect accuracy, 'every case would involve a rights violation, which hardly fits common intuitions of procedural fairness'.

12 For a defence of the non-negotiable value of participation in tribunal proceedings, see Therese MacDermott's contribution to this volume (Chapter 12).

13 In her contribution to this volume, Emanuela Ceva also defends a version of dignitarianism, arguing that due process has a 'constitutive value', which consists in the way in which it confers the normative status of being an agent or active subject on the parties to legal proceedings (see Chapter 8).

14 See Mackenzie's contribution to this volume (Chapter 9).

\section{References}

Anderson, E 2010, 'The fundamental disagreement between luck egalitarians and relational egalitarians', Canadian Journal of Philosophy, vol. 40, sup 1, pp. 1-23.

Bayles, MD 1990, Procedural justice: allocating to individuals, Kluwer Academic Publishers, Dordrecht.

Bone, RG 1993, 'Statistical adjudication: rights, justice and utility in a world of process scarcity', Vanderbilt Law Review, vol. 46, no. 3, pp. 561-651.

Bone, RG 1999, 'The process of making process: court rulemaking, democratic legitimacy, and procedural efficacy' Georgetown Law Journal, vol. 87, no. 4, pp. 887-955.

Bone, RG 2003, 'Agreeing to fair process: the problem with contractarian theories of procedural fairness', Boston University Law Review, vol. 83, no. 3, pp. 485-552.

Bone, RG 2008, 'Making effective rules: the need for procedure theory', Oklahoma Law Review, vol. 61, no. 2, pp. 319-340.

Bone, RG 2010, 'Procedure, participation, rights', Boston University Law Review, vol. 90, no. 2, pp. 1011-1028. 
Bone, RG 2017, 'Economics of civil procedure', in F Parisi (ed.), The Oxford handbook of law and economics volume 3: public law and legal institutions, Oxford University Press, Oxford.

Dworkin, R 1977, Taking rights seriously, Duckworth, London.

Dworkin, R 1985, 'Principle, policy, procedure', in A matter of principle, Harvard University Press, Cambridge.

Dworkin, R 1986, Law's empire, Belknap Press of Harvard University Press, Cambridge.

Dworkin, R 2002, 'The threat to patriotism', New York Review of Books, 28 February, vol. 44, no. 49, viewed 11 November 2019. Available at https://www.nybooks. com/articles/2002/02/28/the-threat-to-patriotism

Edelman, J 2016, 'Why do we have rules of procedural fairness?', Australian Journal of Administrative Law, vol. 23, no. 31, pp. 144-154.

Galligan, DJ 1996, Due process and fair procedures: a study of administrative procedures, Clarendon Press, Oxford.

Kaplow, L 1994, 'The value of accuracy in adjudication: an economic analysis', Journal of Legal Studies, vol. 23, no. 1, pp. 307-401.

Lind, EA, Lissak, RI \& Conlon DE 1983, 'Decision control and process control effects on procedural fairness judgments', Journal of Applied Social Psychology, vol. 13, no. 4, pp. 338-350.

Mashaw, JL 1981, 'Administrative due process: the quest for a dignitary theory', Boston University Law Review, vol. 61, no. 4, pp. 885-931.

Meyerson, D \& Mackenzie, C 2018, 'Procedural justice and the law', Philosophy Compass, vol. 2018, p. el2548. Available at https://doi.org/10.1111/ phc3. 12548

Plaxton, M 2008, 'Arguments of virtue and constitutional criminal procedure', University of Toronto Law Journal, vol. 58, no. 3, pp. 355-376.

Posner, RA 1973, 'An economic approach to legal procedure and judicial administration', Journal of Legal Studies, vol. 2, no. 2, pp. 399-458.

Posner, RA 1979, 'Utilitarianism, economics and legal theory', Journal of Legal Studies, vol. 8, no. 1, pp. 103-140.

Posner, RA 2011, Economic analysis of law, 8th edn, Aspen Publishers, New York.

Rawls, J 1971, A theory of justice, Oxford University Press, Oxford.

Scheffler, S 2003, 'What is egalitarianism?', Philosophy and Public Affairs, vol. 31, no. 1, pp. 5-39.

Solum, LB 2004, 'Procedural justice', Southern California Law Review, vol. 78, no. 1, pp. 181-321.

Summers, RS 1974, 'Evaluating and improving legal processes-a plea for "process values", Cornell Law Review, vol. 60, no. 1, pp. 1-52.

Tribe, L 1988, American constitutional law, 2nd edn, Foundation Press, Mineola.

Tyler, TR 1987, 'Conditions leading to value-expressive effects in judgments of procedural justice: a test of four models', Journal of Personality and Social Psychology, vol. 52, no. 2, pp. 333-344.

Tyler, TR \& Blader, SL 2000, Cooperation in groups: procedural justice, social identity and behavioral engagement, Psychology Press, Philadelphia.

Tyler, TR \& Lind, EA 1992, 'A relational model of authority in groups', Advances in Experimental Social Psychology, vol. 25, pp. 115-191. 
Tyler, TR \& Lind, EA 2001, 'Procedural justice', in J Sanders \& VL Hamilton (eds.), Handbook of justice research in law, Kluwer Academic/Plenum Publishers, New York.

Tyler, TR, Rasinski, K \& Spodick, N 1985, 'The influence of voice on satisfaction with leaders: exploring the meaning of process control', Journal of Personality and Social Psychology, vol. 48, no. 1, pp. 72-81.

Waldron, J 2011, 'The rule of law and the importance of procedure', in JE Fleming (ed.), Getting to the rule of law, New York University Press, New York/London.

Weinrib, EJ 1980, 'Utilitarianism, economics, and legal theory', University of Toronto Law Journal, vol. 30, no. 3, pp. 307-332. 